\title{
Fibronectin in Neoplastic Peritoneal Effusions in Dogs
}

\author{
By Bernhard F. Feldman, Erik Brummerstedt, Liselotte S. Larsen and Steen Larsen.
}

\begin{abstract}
Feldmann, B., E. Brummerstedt, L. S. Larsen and Steen Larsen: Fibronectin in neoplastic peritoneal effusions in dogs. Acta vet. scand. 1988, 29, 273-279. Fibronectin is a glycoprotein found in soluble form in plasma and in an insoluble form in connective tissue matrices. Fibronectin isolated from canine peritoneal effusions by affinity chromatography on gelatin-Sepharose was found to be immunologically indistinguishable from the plasma form, as shown by double immunodiffusion techniques. Utilizing an enzyme immunoassay technique, 7 patients with disseminated splenic hemangiosarcoma were found to have peritoneal fibronectin concentrations of $309 \pm 133$ (mean \pm SD) $\mu \mathrm{g} / \mathrm{ml}$. In 8 patients with widespread lymphoma the peritoneal fibronectin concentrations were $323 \pm 147$ $\mu \mathrm{g} / \mathrm{ml}$. In 5 patients with hepatoma the peritoneal fibronectin concentrations were $361 \pm 121 \mu \mathrm{g} / \mathrm{ml}$. In 6 patients, 2 with mesothelioma, 2 with pancreatic adenocarcinomas, and 2 with prostatic adenocarcinoma, the peritoneal fibronectin concentrations were $315 \pm 115 \mu \mathrm{g} / \mathrm{ml}$. The lowest concentrations $117 \pm 46 \mu \mathrm{g} / \mathrm{ml}$, were found in patients with malignant disease and concurrent peritoneal thrombus formation. These data suggest that decreased fibronectin concentrations in peritoneal effusions are associated with, at least, a locally hypercoagulable state.
\end{abstract}

thrombosis; tumor; canine.

\section{Introduction}

Fibronectin ( $\mathrm{FN})$ is a glycoprotein found in soluble form in plasma and in an insoluble form in connective tissue matrices. Fibronectin was found to be identical with a circulating protein having opsonic properties termed alpha-2-opsonic glycoprotein (Blumenstock et al. 1978). Insoluble FN is also associated with the surface of cells grown in culture and is frequently lost on transformation. It thus acquired a variety of names including large external transformation sensitive (LETS) protein (Hynes \& Bye 1974). The relationship between FN and neoplasia was stimulated by observations that transformation of fibroblasts in vitro by oncogenic viruses is accompanied by loss of this glycoprotein from cell surfaces (Vaheri \& Ruoslahti 1974). When the protein is purified and added to transformed cells, there is reversion of morphology, but not of growth control, towards normal (Ali et al. 1977). The loss of surface FN has also been observed in chemically induced tumors (Clark \& Fink 1977) and in cells from spontaneously occurring tumors (Pearlstein 1976). This is not invariable and exceptions have been reported (Pearlstein 1976). 
Fibronectin is involved with hemostasis as indicated by its interactions with fibrin and its presence in platelets. Plasma FN can be crosslinked to itself and to fibrin by plasma transglutaminase (Factor XIII) (Mosher 1975). Thrombin causes the release of platelet FN antigen and increases its surface expression (Ginsberg et al. 1980).

Plasma opsonic FN, when diminished, results in impairment of the reticuloendothelial system (Saba \& Jaffe 1980). Similarly, impairment of reticuloendothelial function in patients following major surgery, with burns, trauma, or sepsis is associated with diminished plasma FN (Saba et al. 1978, Lanser et al. 1980).

The involvement of FN in neoplasia, hemostasis, reticuloendothelial function, inflammation and tissue repair (D'Ardenne \& $M c G e e$ 1984) and in exudative pleural effusions (Klockars et al. 1982), stimulated us to examine $\mathrm{FN}$ concentrations in neoplastic peritoneal effusions in dogs.

\section{Materials and methods}

\section{Patient selection}

Peritoneal fluid samples were obtained from dogs admitted to the hospital for diagnostic evaluation of peritoneal effusion. The neoplastic etiopathogenesis of the peritoneal effusion was determined by clinical, laboratory, and radiologic findings including diagnostic exfoliative cytology, laparoscopy and laparotomy. Fluids were all culture negative and total nucleated cell counts, differential cell counts, and total protein concentration were routinely determined. Patients for this study were selected because of the constellation of abdominal tumor formation, peritoneal effusion which was inflammatory but nonseptic, complete necropsy, and cytologic and histologic confirmation of tumor. In all, 26 patients which included these criteria were selected. The patients were grouped: splenic hemangiosarcoma (7), hepatoma (5), lymphoma (8) and a diverse group of tumor types (6) which included pancreatic adenocarcinoma (2), prostatic carcinoma (2) and mesothelioma (2). In addition, 5 of the patients had evidence of mesenteric arterial thrombosis, diagnosed on necropsy. These included 2 patients with hemangiosarcoma, both patients with mesothelioma, and 1 patient with pancreatic adenocarcinoma. Peritoneal fluid was taken into an unstabilized sterile tube for culture, into EDTA and centrifuged for fluid and cell analysis, and sodium citrate for $\mathrm{FN}$ analysis. These latter samples were stored in plastic at $-50^{\circ} \mathrm{C}$ until assayed.

\section{Plasma reference interval and normal pool}

The plasma reference interval (mean $+\mathrm{SD}$, $320+74 \mu \mathrm{g} / \mathrm{ml}$ ) was determined in 132 healthy dogs aged 2 to 8 years and included 71 females and 61 males.

Plasma from 24 healthy adult male dogs made up the normal plasma pool and was determined to contain $315 \mu \mathrm{g} / \mathrm{ml}$ of fibronectin.

\section{Isolation of fibronectin from peritoneal fluid}

Fibronectin in peritoneal fluid was prepared by affinity chromatography and characterized as previously described (Engvall \& Ruoslahti 1977).

\section{Purified canine fibronectin}

Purified canine fibronectin was prepared by affinity chromatography and characterized as described previously (Engvall \& Ruoslahti 1977, Feldman et al. 1985). The purified antigen was stored at $-50^{\circ} \mathrm{C}$. It was thawed at $37^{\circ} \mathrm{C}$ for use and could be refrozen and thawed again up to 3 times without affecting its antigen activity. Fibronectin standards were prepared by serial dilution of the antigen $(1: 10$ to $1: 320)$ in Tris-albumin buffer 
(TAB) containing $10 \mathrm{nM}$ Tris- $\mathrm{HCl}$ (Trizma-HCl, Sigma Chemical Company, St. Louis, Missouri), $150 \mathrm{mmol} / 1$ sodium chloride and $5 \mathrm{mg} / \mathrm{ml}$ bovine serum albumin at a $\mathrm{pH}$ of 7.5. The standard curve ranged from 1.8 to $58 \mu \mathrm{g} / \mathrm{ml} \mathrm{FN}$.

\section{Canine fibronectin antiserum}

Canine fibronectin antiserum was prepared as described previously (Feldman et al. 1985) in New Zealand White rabbits. Rabbit anticanine immunoglobulin $\mathrm{G}$ was purified by precipitation with saturated ammonium sulfate (Garvey et al. 1982). The precipitate was redissolved and dialyzed in $0.01 \mathrm{~mol} / \mathrm{l}$ carbonate buffer. Aliquots of this immunoglobulin $\mathrm{G}$ were stored at $-50^{\circ} \mathrm{C}$. Nine $\mathrm{ml}$ of normal canine plasma pool constituents and samples for the determination of a normal fibronectin range as well as plasma and peritoneal effusion fluid for this study were collected into plastic syringes containing $1 \mathrm{ml}$ of $3.8 \%$ sodium citrate for a final ratio of 1 part citrate to 9 parts whole blood or fluid.

\section{Fibronectin and protein in peritoneal fluid}

The concentration of $\mathrm{FN}$ in peritoneal fluid was determined by enzyme immunoassay (ELISA) as described (O'Neill et al. 1986). Using a sample volume of $5 \mu \mathrm{l}$ using purified canine plasma fibronectin and normal canine plasma as standards. Protein was determined by standard Biuret method.

\section{Immunodiffusion analysis}

These tests were made according to the diffusion gel methods described by Ouchterlony (1958).

\section{Statistical analysis}

Data were analyzed utilising Student's t-test.

\section{Results \\ Identification of fibronectin in peritoneal fluid}

Fibronectin was found in all canine peritoneal fluid samples and exhibited immunologic identity to plasma $\mathrm{FN}$ of dogs in double diffusion tests.

\section{Concentrations of fibronectin in neoplastic peritoneal effusions}

Plasma and peritoneal fibronectin concentrations were determined concurrently. Compared with the amount of FN in plasma samples the concentration of neoplastic peritoneal fluid FN was not significantly ( $p>$ 0.05 ) different. There was no correlation between the amount of protein and the total nucleated cell count or any particular cell type within the differential distribution. Since the neoplasms were not staged, no attempts were made to correlate the duration or clinical severity of the lesions and the peritoneal fibronectin concentrations. The concentrations of $\mathrm{FN}$ in the peritoneal fluids are summarized in Table 1.

There was not a statistically significant difference ( $p>0.05$ ) between the FN concentration in the peritoneal effusion in the 4 tumor groupings. Nor were there any significant difference in plasma concentrations of FN between these groupings. However, there was a significant difference $(\mathrm{p}<0.01)$ between the means of the study population or the means of the individual groupings and the means of 5 patients in which mesenteric arterial thromboses of variable size were discovered. These 5 patients had the lowest concentrations of FN both individually and as a group.

\section{Discussion}

A recent review of $\mathrm{FN}$ in disease outlines its role in inflammation and repair of tissues, in neoplasia, in reticuloendothelial function, 
Fibronectin maintains cell to cell contacts and is inversely correlated with the metastatic potential of transformed cells $(\mathrm{McDo}$ nagh 1981). As abnormal morphology of transformed cells may be reversed by addition of $\mathrm{FN}$ in vitro, there appears to be an inverse relationship between the expression of extracellular FN and cell transformation. There may be several explanations for the relationship between FN, cell transformation and oncogenicity. The extracellular matrix functions in control of growth. Cells that have lost their matrix would be more likely to undergo unregulated growth. The possibility that $\mathrm{FN}$ is related with invasiveness and metastatic potential is supported by experimental results that benign tumors did not lose their extracellular FN matrix whereas metastatic tumors did (Chen et al. 1978).

Fibronectin is also a plasma protein which regulates the hemostatic process. Fibronectin has a fibrin crosslinking domain close to or identical with the collagen crosslinking domain and accounts for the lower concentrations of this glycoprotein in serum (McDonagh 1981). It has also been found that both FN and its plasmin degradation products enhance the initial rate of urokinase activation of plasminogen (Iwanaga et al. 1978). In vivo FN may directly affect the lysis rate of a thrombus. As described above, patients with disseminated intravascular coagulation have decreased concentrations of FN. While none of the patients selected in this study were studied biochemically for the existence of disseminated intravascular coagulation and it was not observed on necropsy, the possibility exists that this complex process was extant in the 5 cases in which FN concentrations were lowered.

In conclusion the results of this study suggest that lowered FN concentrations may facilitate a hypercoagulable state. Hyper- coagulability has been defined as "an altered state of circulating blood that requires a smaller quantity of clot promoting substances to induce intravascular coagulation than is required to produce comparable thrombosis in a normal subject" (Wall \& Harker 1980). Deficiencies in FN in evolving malignancies may be equivalent to progressive tumor growth and metastatic invasion. The invasion of tumor into tissues and the consequent release of thromboplastins would activate the hemostatic system. Activated coagulation proteins, platelets and, tumor cells, opsonized by FN, could reduce mononuclear phagocyte system effectiveness and thereby potentiate the various faces of thrombosis. The study of FN in plasma and body fluids of various disease states continues to be of interest.

\section{Acknowledgement}

This project was supported by the Danish Agricultural and Veterinary Research Council, grant No. 13-3682.

\section{References}

Ali IU, Mautner V-M, Lanza RP, Hynes RO: Restoration of normal morphology, adhesion, and cytoskeleton in transformed cells by addition of a transformed sensitive surface protein. Cell 1977, 10, 115-122.

D'Ardenne AJ, McGee JO'D: Fibronectin in disease. J. Path. 1984, 142, 235-251.

Bing DH, Alameda S, Isliker H, Lahav J, Hynes $R O$ : Fibronectin binds to the $\mathrm{Clq}$ component of complement. Proc. Natl. Acad. Sci. U.S.A. $1982,79,4198-4201$.

Blummenstock F, Saba TM, Weber P, Laffin R: Biochemical and immunological characterization of human opsonic alpha 2 SB glycoprotein: its identity with cold-insoluble globulin. J. Biol. Chem. 1978, 253, 4287-4291.

Chen LB, Burridge K, Murray A: Modulation of cell surface glycocalyx: studies on large, external, transformation sensitive protein. Ann. N.Y. Acad. Sci. 1978, 312, 366-381. 
Clark SN, Fink LM: Studies on the iodinated surface membrane proteins and concanavalin A agglutination of transformed Syrian hamster cells. Biochim. Biophys. Acta. 1977, 464, 433-440.

Engvall E, Ruoslahti E: Binding of soluble form of fibroblast surface protein, fibronectin, to collagen. Int. J. Cancer, 1977, 20, 1-5.

Feldman BF, Thomson DB, O'Neill SL: Plasma fibronectin concentrations in dogs with disseminated intravascular coagulation. Amer. J. vet. Res. 1985, 46, 1171-1174.

Garvey JS, Cremer NE, Sussdorff DH: Methods in immunology: a laboratory text for instruction and research. Third Edition, Benjamin/ Cummings Publishing Company, 1982, 218219.

Ginsberg MH, Painter RG, Forsyth J, Birdwell C, Plow EF: Thrombin increases expression of fibronectin on platelet surface. Proc. Natl. Acad. Sci., U.S.A. 1980, 77, 1049-1060.

Hynes RO, Bye JM: Density and cell cycle dependence of cell surface proteins in hamster fibroblasts. Cell 1974, 13, 113-117.

Iwanaga S, Suzuki K, Hashimoto S: Bovine plasma cold-insoluble globulin: structure and function. Ann. N.Y. Acad. Sci. 1978, 312, 56-73.

Klockars $\mathrm{K}$, Pettersson T, Vartio T, Riska H, Vaheri A: Fibronectin in exudative pleural effusions. J. clin. Path. 1982, 35, 723-727.

Lanser ME, Saba TM, Scovill WA: Opsonic glycoprotein (plasma fibronectin) levels after burn injury. Ann. Surg. 1980, 192, 776-781.

McDonagh J: Fibronectin, a molecular glue. Arch. Pathol. Lab. Med. 1981, 105, 393-396.

Mosher DF: Cross-linking of cold-insoluble globulin by fibrin-stabilising factor. J. Biol. Chem. 1975, 250, 6614-6625.

Mosher DF, Williams EM: Fibronectin concentration is decreased in plasma of severly ill patients with disseminated intravascular coagulation. J. Lab. Clin. Med. 1978, 5, 729735.

Mosher DF, Proctor RA: Binding and factor XIIIa-mediated crosslinking of a 27-kilodalton fragment of fibronectin to Staphylococcus aureus. Science (Washington D.C.), 1980, 209, 927-929.
O'Neill SL, Boothby JT, Feldman BF: An enzyme immunoassay to measure canine circulating fibronectin. Vet. Clin. Path. 1986, 15, 22-26.

Ouchterlony $\ddot{O}$ : Diffusion-in-gel methods for immunological analysis. In Kallus, D. editor. Progress in Allergy vol. V. S. Karger, Basel, 1958, 1-78.

Pearlstein E: Plasma membrane glycoprotein which mediates adhesion to fibroblasts to collagen. Nature 1976, 262, 497-500.

De Russe J, Colombat P, Lavoix X, Bardos P: Plasma fibronectin in various hemopathic diseases. Clin. Chim. Acta 1985, 145, 49-58.

Saba TM, Blummenstock FA, Scovill WA, Bernard $H$ : Cryoprecipitate reversal of opsonic alpha 2-surface binding glycoprotein deficiency in septic surgical and trauma patients. Science 1978, 201, 622-624.

Saba TM, Jaffe EA: Plasma fibronectin (opsonic glycoprotein): its synthesis by vascular endothelial cells and role in cardiovascular integrity after trauma as related to reticuloendothelial function. Amer. J. Med. 1980, 68, 577594.

Vaheri A, Ruoslahti E: Disappearance of a major cell type specific surface glycoprotein antigen (SF) after transformation by Rous sarcoma virus. Int. J. Cancer, 1974, 13, 579-582.

Wall RT, Harker LA: The endothelium and thrombosis. Ann. Rev. Med. 1980, 31, 361371.

\section{Sammendrag}

Fibronectin i neoplastiske peritoneale effusioner hos hunde.

Fibronectin er et glycoprotein, der forekommer i en opløselig form i plasma og i en uopløselig form $\mathrm{i}$ bindevævsgrundsubstans. Fibronectin isoleret fra peritoneale effusioner hos hunde ved affinitetskromatografi kunne immunologisk ikke skelnes fra plasmaformen ved anvendelse af immunodiffusion. Med enzymimmunoassay fandtes 7 patienter med dissemineret hæmangiosarkom i milten at have en peritoneal fibronectinkoncentration på $309 \pm 133$ (gns. \pm SD) $\mu \mathrm{g} / \mathrm{ml}$. Hos 8 patienter med udbredt lymfom var koncentrationen $323 \pm$ $147 \mu \mathrm{g} / \mathrm{ml}$ og hos $5 \mathrm{dyr}$ med hepatom $361 \pm 121$ $\mu \mathrm{g} / \mathrm{ml}$. Hos 6 patienter, hvoraf 2 med mesothe- 
liom, 2 med pancreasadenokarcinom og 2 med prostatakarcinom, var koncentrationen af fibronectin i peritonealvæsken $315 \pm 115 \mu \mathrm{g} / \mathrm{ml}$. De laveste koncentrationer, nemlig $117 \pm 46 \mu \mathrm{g} / \mathrm{ml}$ blev fundet hos patienter med neoplasi ledsaget af dannelsen af thromber $\mathrm{i}$ mesenteriets arterier. Disse data peger på, at nedsat indhold af fibronectin i peritoneale effusioner er ledsaget af øget koagulation i hvert fald lokalt.

(Received December 23, 1987).

Reprints may be requested from: B. F. Feldman, Department of Clinical Pathology,

School of Veterinary Medicine, University of California, Davis, California 95616, U.S.A. 
